Jusmal llmial

PEUR AA DE

Vol. 5, No. 2, May 2017

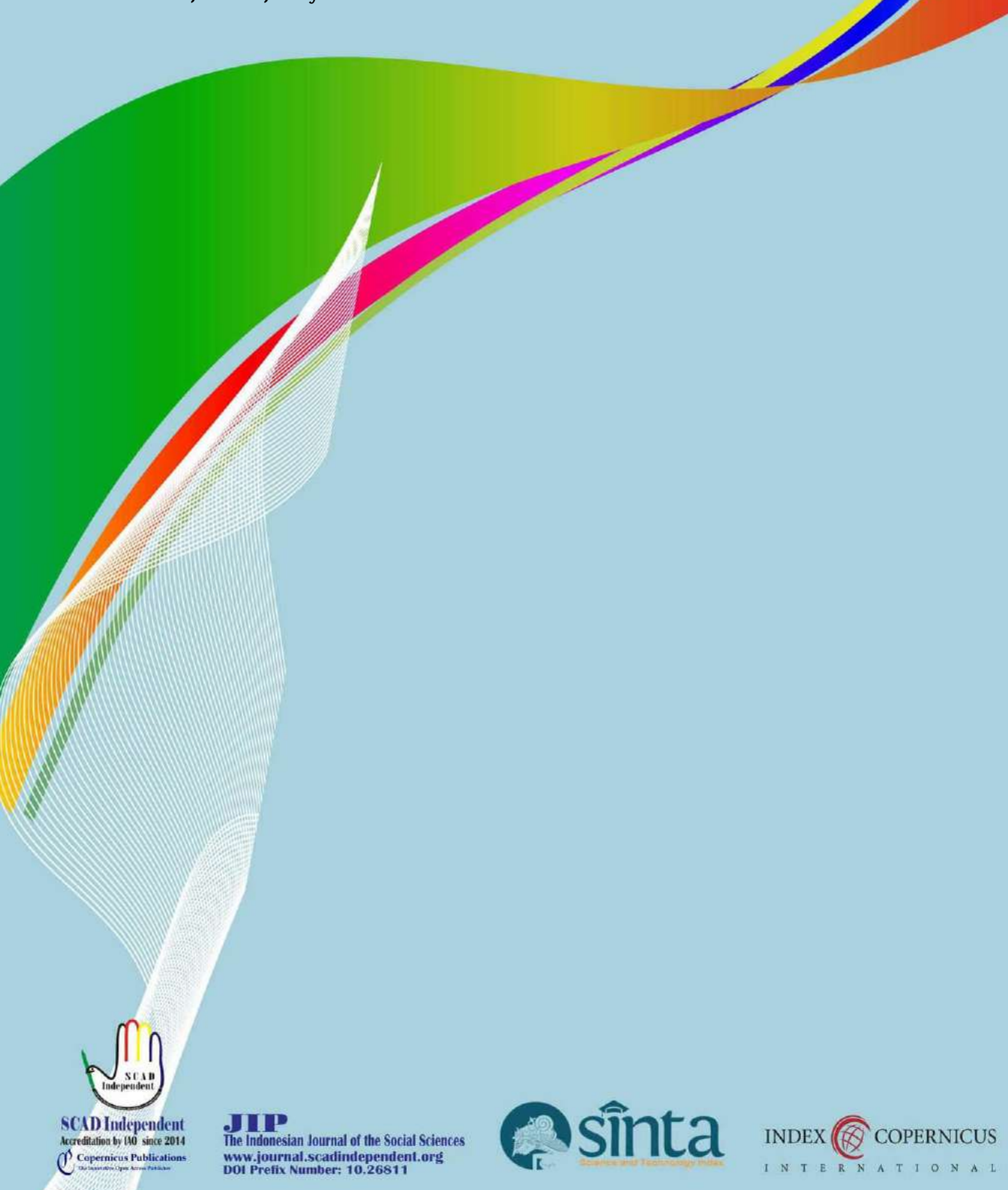




\title{
INCREASING OF STUDENTS' MOTIVATION IN LEARNING PHYSICS THROUGH THE USE OF COMPUTER SIMULATION MEDIA VIEWED FROM PARENTS' EMPLOYMENT BACKGROUND
}

\author{
Yusrizal $^{1}$ \& Khairul Hanif ${ }^{2}$ \\ 1,2Syiah Kuala University, Indonesia \\ ${ }^{1}$ Contibutor Email: yusrizal_fkipunsyiah@yahoo.co.id
}

Received: March 23, 2017

Accepted: May 4, 2017

Published: May 27, 2017

Article Url: http://journal.scadindependent.org/index.php/jipeuradeun/article/view/129

\begin{abstract}
This study aims to determine the increasing of high school students' motivation in learning physics through the use of computer simulation media in terms of parents' employment background. The method used in this study is quasi-experimental method. This research was conducted in class X SMAN 1 Lhoknga Aceh Besar. The data collection was gathered by giving a pretest and posttest questionnaire of student motivation. Then, the administration of a questionnaire survey was conducted to find out the background of the parents' employment. The results of the study showed that the use of computer simulations media could increase student motivation. The survey results showed that in the experimental class the student whose father works as a vegetable seller and his mother as a housewife got the highest increase of motivation. Furthermore, students who experienced the lowest increase of motivation both parents were victims of tsunami disaster in 2004. In the control class, students who experienced the highest increase of motivation came from a family whose father works as a fisherman and his mother is a housewife. Whereas, Students who obtained the lowest increase of motivation, his father has temporary jobs and his mother is a housewife.
\end{abstract}

Keywords: Media Computer Simulation, Student Motivation, Parents' job 


\section{A. Introduction}

In the process of learning, physics has a long tradition that is considered as difficult subjects (Krips, 1993; Angell et al., 2004). One of the reasons why physics is categorized difficult is because most students have less motivation when learning physics. The lesson that is considered difficult to be understood in depth when students are motivated to learn. A case study conducted in SMAN 1 Lhoknga in September 2014 showed some summary of the issues related to student motivation in learning physics.

The results of interviews with teachers of physics in schools showed that students are less motivated when learning physics. Judging from the means, the school already has a complete teaching facility for the process of learning physics. This study tried to see the development of student motivation through the use of computer simulations media, then conducted further review of the background of the parents' employment of students who have increased highs and lows motivation. Learning topics selected were the topic of heat transfer. Data from the National Examination for such material, in 2012 the value of students on the ability of mastering the material has a percentage of $89 \%$. Furthermore, in 2013 the percentage of mastery is $56 \%$ while in 2014 the percentage of mastery of only 70\% (Puspendik, 2012, 2013, 2014). These data show that mastery of the material of heat transfer in 2014 was relatively lower than in 2012.

Student motivation can be improved either by using the medium of animation or computer simulations. Traditional learning is no longer interest to students, teachers should introduce a more modern media to enable students to become more interested in learning physics, it can build interest (motivation) of students (Renata and Jana, 2012). Simulation is a best cognitive representation to understand the depth concept of a reality, because the simulation to learn the methods of a science, a variety of knowledge using various simulations (Yanoff and Weirich, 2010), by using computer simulations students can extract important information, so it can be better understand the concept of a material (Fang and Guo, 2016). Computer simulation is a visual media that is used to understand the workings of a system (Stephens, 2015). In the education sector, the computer simulation has followed the rapid development of computer 
applications, the teachers need to reduce complexity and simplify the ideas being studied, because of the lack of simplification representation of an idea can be an obstacle to support student learning (Renken et al., 2015: 5 -14).

Media computer simulation can be displayed through electronic devices that monitor or projector so the use of time in learning can be more efficient. Obstacles often faced by teachers in implementing the learning using inquiry approach are the limited tools, materials and limited allocation of time. So to respond to this matter, teachers can use computer simulations media combined with interactive demonstrations (Wijaya, 2012). The motivation of the students not only from the media used in the school environment, but can also come from environmental factors when students are at home. Students who have parents with socio-economic backgrounds will have different intellect and a different motivation in learning (Kriegbaum and Spinath, 2016; Dotterer et al., 2009). Based on the above explanation, the purpose of research is to determine the increase of student motivation through the use of computer simulation media in terms of parents' employment background.

\section{B. Method}

This research used a quasi-experimental pretest / posttest. Thus, in the study there are two sample classes: one class gets learning using computer simulations (experimental group) and the other class got conventional learning (control group). Selection of class $\mathrm{X} 1$ and $\mathrm{X} 3$ as the study sample was based on the teacher's explanation that the three classes in the class $\mathrm{X}$ at the school have the same ability. Random sampling technique is used to determine the experimental class and control class. Random sampling techniques used in the study is the technique of the drawing is to create a roll of paper that was written a number of sample groups, then be a draw (Soepono, 2002: 85).

Selection of these two classes is also reinforced by the score of physics in previous material provided by the teacher. This shows that the two classes have the ability homogeneous. The instrument used in this study is a questionnaire instrument student motivation and work background questionnaire survey of parents that have been validated by expert. 


\section{Contents of Journal and Discussion}

The results of this study indicate an increase in student motivation of experimental and control class. Increased motivation is focused from differences in the background of parents and learning media used is a comparison between modern learning (using simulation) and conventional learning (without simulation).

\section{The Background of Parents' Job}

The research sample selected in both classes have parents with different socio-economic backgrounds. Parents' background differences in socio-economic influence the achievement of students when learning in schools (Kriegbaum and Spinath, 2016), socio-economic status of parents is usually indicated on the employment and earnings (Bradley \& Corwyn, 2002; Steinmayr et al., 2010). From the results of the survey show that the majority of students in the both sample class came from a family of non-civil servants with different professions. In the control class seen that $38.24 \%$ of parents is a housewife, and $20.59 \%$ are deceased and $11.76 \%$ has been working as a farmer fields while the profession of parents as civil servants only $2.94 \%$, others work as private employees, grocers, teachers, odd jobs, and entrepreneurs. In the experimental class the highest percentage of parents profession also as a housewife with amount $38.24 \%$, then $14.71 \%$ as rice farmers, and $11.76 \%$ had deceased, while for civil servants in this class reached $8.82 \%$, others work as a builder, a chicken farmer, fisherman, private employees, grocers, teachers and odd jobs. For more details, parents' employed background data can be seen in Table 1 and Table 2 .

Table1. The percentage of parents in the work of the control class

\begin{tabular}{|l|c|}
\hline \multicolumn{1}{|c|}{ Parents' Employment } & Percentage \\
\hline Farmer & 11,76 \\
\hline Driver & 5,88 \\
\hline Odd job & 5,88 \\
\hline Private Employee & 2,94 \\
\hline Housewife & 38,24 \\
\hline Grocer & 2,94 \\
\hline Fisherman & 2,94 \\
\hline
\end{tabular}




\begin{tabular}{|l|c|}
\hline \multicolumn{1}{|c|}{ Parents' Employment } & Percentage \\
\hline Teacher & 2,94 \\
\hline Entrepreneur & 2,94 \\
\hline Civil Servant & 2,94 \\
\hline Alm. Total & 20,59 \\
\hline \multicolumn{2}{|c|}{ T00 } \\
\hline
\end{tabular}

Tabel 2. The percentage of the work of parents of students in the experimental class

\begin{tabular}{|l|c|}
\hline \multicolumn{1}{|c|}{ Parents' Employment } & Percentage \\
\hline Farmer & 14,71 \\
\hline Driver & 0,00 \\
\hline Odd Job & 2,94 \\
\hline Private Employee & 2,94 \\
\hline Housewife & 38,24 \\
\hline Grocer & 2,94 \\
\hline Fisherman & 5,88 \\
\hline Teacher & 2,94 \\
\hline Builder & 5,88 \\
\hline Civil Servant & 8,82 \\
\hline Alm. & 11,76 \\
\hline Chicken Farmer & 2,94 \\
\hline \multicolumn{1}{c|}{ Total } & $\mathbf{1 0 0}$ \\
\hline
\end{tabular}

2. Students' Motivation Result

The motivation of students in both classes increased differently. The increased in the average score of the students' motivation in class control can be seen in Figure 1

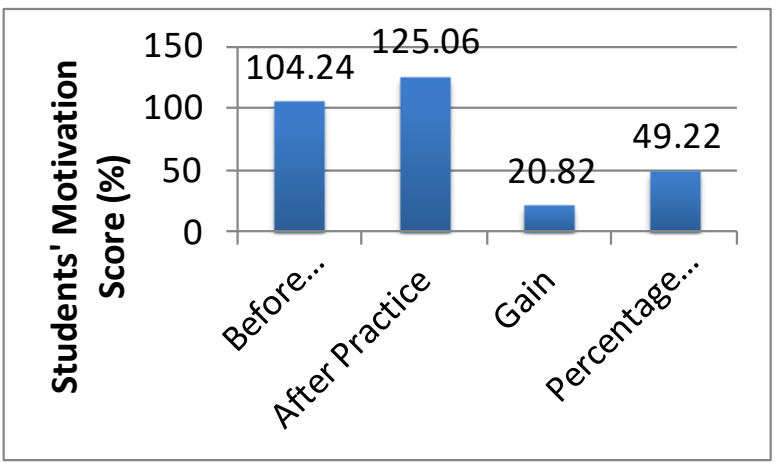

Figure 1. The increase in the average score of the students' motivation in class control 
The increased motivation of students in control class for each indicator can be seen in Table 3.

Table 3. Increased motivation control class to each indicator

\begin{tabular}{|c|c|c|c|c|c|c|}
\hline No & Factor & Indicator & $\begin{array}{l}\text { Pretest } \\
\text { class } X^{1}\end{array}$ & $\begin{array}{l}\text { Posttest } \\
\text { class } X^{1}\end{array}$ & $N$-gain & Category \\
\hline 1 & \multirow{3}{*}{ Intrinsic } & 1 & 54,75 & 67,25 & 41,32 & Medium \\
\hline 2 & & 2 & 52,83 & 59,67 & 21,24 & Low \\
\hline 3 & & 3 & 51,33 & 61,67 & 30,69 & Medium \\
\hline 4 & \multirow{3}{*}{ Extrinsic } & 4 & 51,33 & 62,00 & 31,68 & Medium \\
\hline 5 & & 5 & 49,25 & 62,13 & 36,01 & Medium \\
\hline 6 & & 6 & 56,25 & 63,25 & 24,35 & Low \\
\hline
\end{tabular}

Table 3 shows that the score of control class motivation improvement on indicator 2 (existence of motivation and need in learning) and indicator 6 (existence of a conducive learning environment) increased with low category with N-gain 21,24 and 24,35 respectively. For other indicators: indicator 1 (The desire and desire succeed), indicator 3 (The existence of hope and future aspirations), indicator 4 (The existence of awards in learning) and indicator 5 (The existence of activities interesting in learning) experience Increase with $\mathrm{N}$-gain in the medium category. These six indicators become a reference to see the increase in motivation that occurs in learning (Uno, 2008).

The motivation of students in the control class for each individual student also increased which showed a positive improvement. The highest increase occurred with $\mathrm{N}$-gain of $68.63 \%$ and the lowest increase occurred with $\mathrm{N}$-gain is $0 \%$. The home environment can also affect the intrinsic motivation of students while learning (Gottfried et al., 1998), it is natural for every student who comes from a different economic background will have different learning achievement (Berger and Archer, 2016). The survey results showed that both students who have increased the motivation of those classes have the same learning facility when he was in the house, however students who achieved the highest increase has better awareness to learn at home than students who achieved the lowest 
increase. Judging from the background work of parents, students who achieved the highest increase his father had a job as a fisherman and his mother as a housewife. Students who achieved the lowest increase his father worked odd jobs and his mother as a housewife

Motivation of students in the experimental class has positive improvements. This is the same as it did in the control class; there are differences in scores after learning with prior learning. If paid more attention, the increased motivation that occurs in the experimental class is better than the control class, as shown in Figure 2.

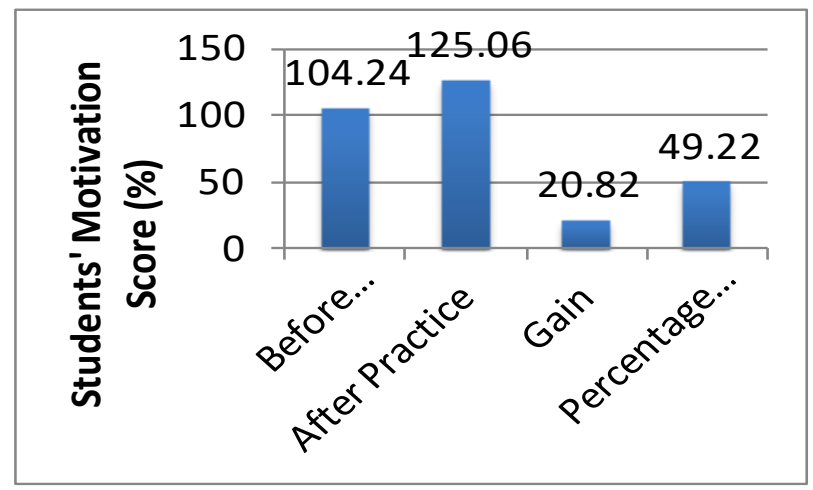

Figure 2. The increase in the average score of students in the experimental class motivation

Table 4. Increasing student motivation experimental class in each indicator

\begin{tabular}{|c|c|c|c|c|c|c|}
\hline No & Factor & Indicator & $\begin{array}{c}\text { Pretestclass } \\
\mathrm{X}^{3}\end{array}$ & $\begin{array}{c}\text { Posttestclass } \\
\mathrm{X}^{3}\end{array}$ & $\begin{array}{c}N- \\
\text { gain }\end{array}$ & Category \\
\hline 1 & \multirow{3}{*}{ Intrinsic } & 1 & 65,00 & 78,00 & 65 & Medium \\
\hline 2 & & 2 & 62,00 & 76,17 & 61,59 & Medium \\
\hline 3 & & 3 & 65,00 & 72,67 & 38,33 & Medium \\
\hline 4 & \multirow{3}{*}{ Extrinsic } & 4 & 61,33 & 73,33 & 50,70 & Medium \\
\hline 5 & & 5 & 62,75 & 76,75 & 62,92 & Medium \\
\hline 6 & & 6 & 64,75 & 76,25 & 56,79 & Medium \\
\hline
\end{tabular}

Table 4 shows an increase in motivation of students' in experimental class. Indicator 1 (existence of desire and willingness to succeed), indicator 2 (existence of encouragement and need in learning), 
indicator 3 (Presence of hope and future aspiration), indicator 4 (The existence of awards in learning), indicator 5 (Interesting activity In learning), and indicator 6 (The existence of a conducive learning environment). All of these indicators improved in the medium category and the highest increase occurred in indicator 1 (the desire to succeed) with N-Gain $65 \%$. Student motivation in this class if viewed from each individual student also improved. The highest increase occurred with $\mathrm{N}$ gain $96.10 \%$ and the lowest increase occurred with $0 \% \mathrm{~N}$-gain.

The survey results showed that students who experienced the lowest increase had better learning facilities when at home than students who experienced the highest increase. In addition to facilities, student motivation is also related to his personality. The personality of each student depends on the background of his family (Roskam, 2001). Judging from the background of the work of the parents of the students in the experimental class, the student who experienced the highest motivational improvement of his father had a job as a grocer and his mother as a housewife, the students who experienced the lowest increase of both parents had been affected by the tsunami disaster in 2004. Judging from the two classes Samples, this study may show that different parent backgrounds can influence variations in student motivation in learning (Archer, 2009, Gottfried et al., 1998; Ginsburg, 1993).

After further analysis of the motivation of both classroom posttest scores by using $\mathrm{t}$-test, it is found that the absolute value of $\mathrm{t}=3.54>$ table $=$ 2.12. Thus we can conclude that both classes have increased motivation significant difference with $\mathrm{N}$-gain average experimental class grade of $49.22 \%$ and $\mathrm{N}$-gain average control class grade $34.08 \%$. From the difference of $\mathrm{N}$-gain is seen that increased motivation classes using computer simulation is better than classes that do not use a computer simulation (Vogel et al., 2006; Rutten et al., 2012; Özdemir and Oner. 2015).

\section{Conclusion}

The results showed that in the experimental class students who experienced the highest motivation increase his father had a job as a grocer and 
his mother as housewives; students who experienced the lowest increase of both parents have been deceased by the tsunami 2004. In the control class, students who experienced the highest increase His father has a job as a fisherman and his mother as a housewife, students who experienced the lowest increase his father worked odd jobs and his mother as a housewife. Thus, this study may show that different parents' backgrounds can influence the variation in student motivation in learning. In addition, it can be concluded that the increase in student motivation in physics learning through the use of computer simulation media is significantly better than learning that does not utilize computer simulation.

\section{Bibliography}

Angell, C., Guttersrud, O., Henriksen, E.K and Isnes, A. (2004). Physics: Frightful, But Fun. Pupils' and Teachers' View of Physics and Physics Teaching. Journal of Science Education, 88(5):683-706.

Archer, J. (2009). Motivational implications of the quality teaching model in New South Wales. In C. Ng \& P. D. Renshaw (Eds.), Reforming learning: Concepts, issues and practice in the Asia-Pacific region (pp. 277-291). Amsterdam: Springer

Berger, N and Archer,J. (2016). School socio-economic status and student socio-academic achievement goals in upper secondary context. Journal Social Psychology of Education, 19:175-194

Bradley, R. H., and Corwyn, R. F. (2002). Socio-economic status and child development. Annual Review of Psychology, 53: 371-399

Dotterer, A. M., McHale, S. M., and Crouter, A. C. (2009). The development and correlates of academic interest from childhood to adolescence. Journal of Educational Psychology, 101(2):509-519

Fang, N and Guo, Y. (2016). Interactive computer simulation and animation for improving student learning of particle kinetics. Journal Of Computer Assisted Learning, issn 1365-2729, (http://dx.doi.org/10.1111/jcal.12145)

Ginsburg, G. S., \& Bronstein, P. (1993). Family factors related to children's intrinsic/extrinsic motivational orientation and academic 
performance. Journal of the Society for Research in Child Development JSTOR, 64(5), 1461-1474

Gottfried, A., Fleming, J., and Gottfried, A. (1998). Role of cognitively stimulating home environment in children's academic intrinsic motivation: A longitudinal study. Journal of Child Development, 69(5), 1448-1460

Kaylene, P., \& Rosone, T. (2016). Multicultural Perspective On The Motivation of Students in Teaching Physical Education. Jurnal Ilmiah Peuradeun, 4(1), 115-126.

Kriegbaum, K and Spinath, B. (2016). Explaining social disparaties in mathematical achievement : The Role Of Motivation. European Journal of Personality, 30(1):45-63

Krips, F. 1993. Mengapa pelajaran fisika selalu paling jelek. Jurnal Pengajaran MIPA, 1(1):39-43.

Özdemir,O and Öner, I.E. (2015). The effects of simulations and animations on students' motivation in a computer course. Journal of Participatory Educational Research, 2:53-59.

Puspendik. (2012). Laporan Hasil Ujian Nasional. Jakarta: Balitbang Kemdikbud. . (2013). Laporan Hasil Ujian Nasional. Jakarta: Balitbang Kemdikbud. . (2014). Laporan Hasil Ujian Nasional. Jakarta: Balitbang Kemdikbud.

Renata, B and Jana, M. (2012). Elearning as a motivation in teaching physics. Procedia Social and Behavioral Science, 64:328-331.

Renken, M., M. Peffer, K.Otrel, I. Girault and A. Chiocarriello. (2015). Computer Simulations on a Multidimensional Continuum: A Definition and Examples. AECT : Springer International Publishing.

Roskam, I., Vandenplas-Holper, C., and De Maere-Gaudissart, A. (2001). Mothers' and teachers' ratings of children's personality: Children's age, gender, scholastic performance, mothers' educational level, and rater effects. European Review of Applied Psychology, 51(4):289-303.

Rutten, N., van Joolingen, W.R and van der Veen, J.T. (2012). The learning effects of computer simulations in science education. Journal Computer \& Education, 58(1):136-153.

Soepono, B. (2002). Statistik Terapan dalam penelitian ilmu-ilmu sosial dan pendidikan. Jakarta : Rineka Cipta. 
Steinbach, M., \& Afroozeh, S. (2016). Comparative Education in The Educational Systems and Problems in Likenesses and Differences Between Regions of The World. Jurnal Ilmiah Peuradeun, 4(3), 333-346.

Steinmayr, R., Dinger, F.C., and Spinath, B. (2010). Parents' education and children's achievement: The role of personality. European Journal of Personality, 24: 535-550.

Stephens, A.L and Clement, J.J. (2015). Use of physics simulations in whole class and small group settings: Comparative case studies. Journal Computer \& Education, 86:137-156.

Uno, H.B. 2008. Teori Motivasi dan Pengukurannya. Jakarta: PT. Bumi Aksara

Vitoria, L., \& Monawati, M. (2016). Improving Students' Problem Solving Skill in Mathematics Through Writing. Jurnal Ilmiah Peuradeun, 4(2), 231-238.

Vogel, J.J., Vogel, D.S., Bower, J.C., Bower, C.A., Muse, K., and Wright, M. (2006). Computer gaming and interactive simulations for learning : A MetaAnalysis. Journal Educational Computing Research, 34(3):229-24.

Wijaya, K.W.B., Kirna, M and Suardana, M. (2012). Model demonstrasi interaktif berbantuan multimedia dan hasil belajar ipa aspek kimia smp. Jurnal Pendidikan dan Pengajaran, 45(1):88-98.

Yanoff, T.G and Weirich, P. (2010). The philosophy and epistemology of simulation : A Review. Simulation and Gaming Journal, 41(1):20-50. 
p-ISSN: 2338-8617

Vol. 5, No. 2, May 2017 e-ISSN: 2443-2067 